\title{
Tidal and diurnal periodicity in macrocrustaceans and demersal fish of an exposed sandy beach, with special emphasis on juvenile plaice Pleuronectes platessa
}

\author{
Bregje Beyst, Jan Vanaverbeke*, Magda Vincx, Jan Mees** \\ Marine Biology Section, Biology Department, Ghent University, K.L. Ledeganckstraat 35, 9000 Gent, Belgium
}

\begin{abstract}
Macrocrustaceans and juvenile demersal fish were sampled in spring of 1997 in the surf zone of an exposed sandy beach on the Belgian coast. Three consecutive $24 \mathrm{~h}$ cycles were sampled to investigate tidal, diurnal and semi-lunar distribution patterns within the epibenthic community. Multivariate statistical techniques and 3-way ANOVA were used to evaluate the effects of the environmental variables measured. The most important variable correlated with the variation in epibenthic catch density was the state of the tide (ebb and flood), but light intensity (day and night) was also important. The individual catch density of several species differed significantly over the three $24 \mathrm{~h}$ cycles. Despite the strong turbulent conditions of the site studied, clear tidal (e.g. the brown shrimp Crangon crangon, juvenile plaice Pleuronectes platessa) and diurnal (e.g. juvenile sole Solea solea and clupeids, caught mainly during the night/day respectively) periodicities of many macrocrustacean and demersal fish species were observed. Nevertheless, the extremely turbulent conditions of the surf zone possibly affect the behaviour of many species (e.g. juvenile brown shrimp are not able to bury themselves as the water retreats). To investigate whether the high dynamics of the surf zone suppress the ability of juvenile plaice to actively search for food, stomach contents were analysed. Also, the interaction with potential prey was investigated: the hyperbenthic fauna was sampled simultaneously and macrobenthic data were available from the literature. Clearly, the Belgian sandy beaches are used as a feeding ground by I-group plaice. An opportunistic utilisation of available food resources is suggested. I-group plaice migrate high up the beach during the flood tide to profit from the rich macrobenthic intertidal area, while the 0-group feeds mainly on the most abundant hyperand macrobenthic organisms from somewhat deeper water. The presence of the 0-group in the intertidal area is possibly linked to refuge for predators or influenced by the strong surf zone currents.
\end{abstract}

KEY WORDS: Surf zone - Sandy beach - Pleuronectes platessa $\cdot$ Crangon crangon - Feeding periodicity $\cdot$ Stomach content analyses $\cdot$ Tidal migration

\section{INTRODUCTION}

Tidal and diurnal periodicity in epibenthic macrocrustaceans and demersal fish of surf zones of sandy beaches, although rarely studied together, are well

\footnotetext{
*Corresponding author. E-mail: jan.vanaverbeke@rug.ac.be ${ }^{* *}$ Present address: Flanders Marine Institute, Victorialaan 3, 8400 Oostende, Belgium
}

documented (e.g. Edwards 1958, Janssen \& Kuipers 1980, Burrows et al. 1994, Gibson et al. 1996). Most studies, however, only examined sheltered or semi-exposed beaches. Data on exposed coasts are rare and restricted mainly to the southern hemisphere. Although these exposed beaches are highly dynamic, they can harbour many species, often in high densities and biomasses (e.g. Clark et al. 1996). Their importance is probably highly underestimated. The hyper- and epi- 
benthic communities of the surf zones of the exposed Belgian sandy beaches have been studied intensively by the present authors; spatial and temporal distribution patterns will be published elsewhere (e.g. Beyst et al. in press).

It is likely that the distribution patterns of intertidal organisms are a mixture of responses to the physical environment modified by direct interactions with other organisms such as predators, competitors or prey (Burrows 1994, Gibson et al. 1998). Data on all of these factors together are rarely available. During this study, an attempt was made to integrate data on the epibenthic surf zone community and their potential prey (hyper- and macrobenthos). Hyperbenthic samples were taken simultaneously and macrobenthic data are available from other studies of an adjacent beach (Elliott et al. 1996, Degraer et al. 1999). Stomach content analyses were used to gain more insight into the feeding ecology of the dominant fish species.

This paper reports the results of an integrated study of the tidal and diurnal rhythms of macrocrustaceans and juvenile demersal fish on an open macrotidal sandy beach on the Belgian coast. The following hypotheses were evaluated: (1) the surf zone of the Belgian coast is too turbulent to detect tidal or diurnal distribution patterns within the epibenthic community; and
(2) its turbulence inhibits the active foraging behaviour in the surf zone of the dominant fish species.

\section{MATERIALS AND METHODS}

Study area. The study area comprises the surf zone of a sandy beach near Nieuwpoort at the exposed Belgian coast in the Southern Bight of the North Sea $\left(51^{\circ} 10^{\prime} \mathrm{N}, 2^{\circ} 45^{\prime} \mathrm{E}\right.$; Fig. 1). The mouth of the Ijzer estuary opens at approximately $2 \mathrm{~km}$ to the west of the site. A strong semi-diurnal tidal regime and a net tidal current running north-east parallel to the coastline are characteristic for the Belgian coast. According to the morphodynamic classification scheme of Masselink \& Short (1993), the beach is classified as a low-tide bar/rip beach. The beach consists of fine sand (median grain size of $200 \mu \mathrm{m}$ ) and is characterised by the presence of groynes approximately $300 \mathrm{~m}$ apart from each other. Several shallow troughs and bars in which the water is retained at low tide run parallel to the water's edge. The site has an intertidal zone of approximately $200 \mathrm{~m}$, with a tidal range of $4.8 \mathrm{~m}$. The difference in water height between spring and neap tide is approximately $1 \mathrm{~m}$.

Sampling. Three campaigns of $24 \mathrm{~h}$ sampling were performed in spring of 1996, at the time of spring (24 to

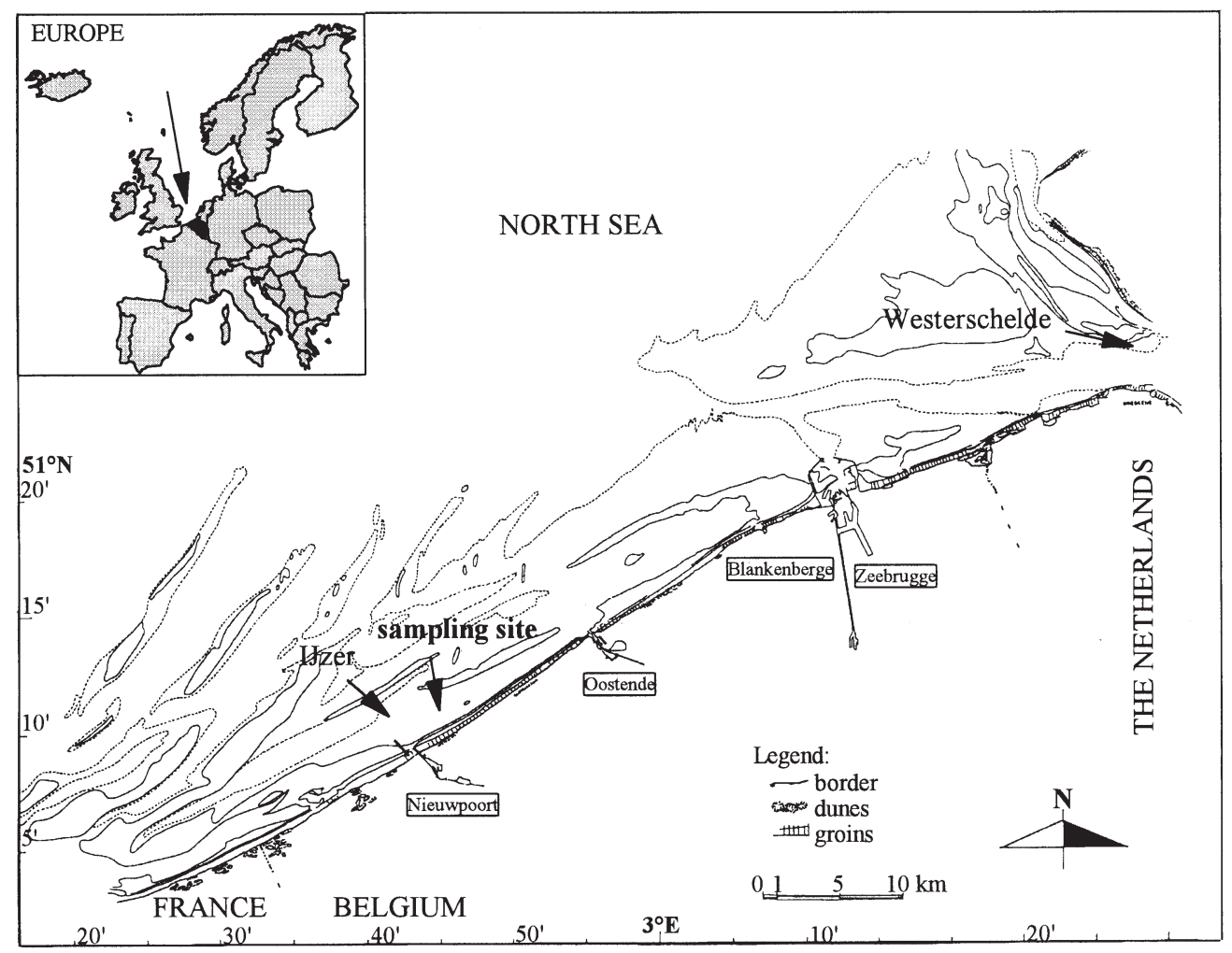

Fig. 1. Study area with indication of sampling site 
25 April) and neap tide (30 April to 1 May) and 1 in between (27 to 28 April). Epi- and hyperbenthic samples were taken alternating every $2 \mathrm{~h}$, starting at 15:00 h Central European Time (CET) with the hyperbenthos and ending the next day also at 15:00 h CET. During the intermediate cycle only, the last sample was taken at 14:00 h CET (epibenthos). This resulted in a total of 36 epi- and 38 hyperbenthos samples. Time constraints and the rapidly changing tidal conditions did not allow replicate hauls to be taken. The hyperbenthos was sampled as it includes many prey items of epibenthic organisms. All epibenthic samples were taken with a $2 \mathrm{~m}$ beam trawl. The net was $3 \mathrm{~m}$ long, had a mesh size of $5 \times 5 \mathrm{~mm}$ and was equipped with a tickler-chain in the ground rope. The hyperbenthos was sampled by means of a hyperbenthic sledge especially designed for this study. Its metal frame measured $100 \times 40 \mathrm{~cm}$ and it was equipped with 2 nets, 1 above the other, each $3 \mathrm{~m}$ long and with a mesh size of $1 \times 1 \mathrm{~mm}$. Both sampling gears were pulled by 2 people in the surf zone parallel to the coastline at a depth of approximately $1 \mathrm{~m}$, following the tide. Each haul lasted 15 or 20 min for the epi- and hyperbenthos respectively and covered a distance of $225 \mathrm{~m}$ back and $225 \mathrm{~m}$ forth, so that the total distance covered by the trawl in each sample was $450 \mathrm{~m}$. The catch was anaesthetised in a dilute solution of benzocaine (ethylamino-4-benzoate) and then preserved in an $8 \%$ formalin solution.

Analysis of samples. In the laboratory, all animals were identified to species, measured and counted, and their standard (or total) length was measured to the nearest millimetre. For the hyperbenthos, total ash free dry weight (ADW) was estimated based on assigned values (cnidarians, ctenophores and small crustaceans) or length-ADW regressions (Mees 1994, Beyst et al. 1999, Dewicke unpubl. data). From the epibenthos, a maximum of 20 juvenile plaice per sample was selected at random from the most abundant size classes caught during spring tide for stomach content analyses. A detailed description of the analyses is given in Beyst et al. (1999). Diet composition was expressed as mean gravimetric percentage and as mean numerical percentage of prey items. The fullness index (FI), a measure of the degree of fullness of the digestive tract (in this case stomach), was used to detect changes in feeding rhythm (Berg 1979).

Environmental variables. Every $2 \mathrm{~h}$, water and sediment samples were taken. Besides some general variables (e.g. salinity, water temperature, sediment analyses), nutrient and pigment concentrations of the water column were measured. These latter factors might give some indications of (potential) primary production. As many prey items of the epibenthic species follow these patterns, they might reveal some important underlying mechanisms. Portable conductivity and oximeters (WTW, Weilheim, Germany) were used for in situ mea- surements of water temperature, salinity and oxygen content. Turbidity was measured with a portable microprocessor turbidity meter (Hanna Instruments, Woonsocket, RI). Water samples were filtered through Whatman GF/F filters, which were frozen immediately. In the laboratory, pigments (chlorophyll- $a$ and $-c$ and fucoxanthine), were immediately extracted with acetone (90\%) before being applied to chromatography. A Gilson HPLC chain was used, following a slightly modified method of Mantoura \& Llewellyn (1983). The concentrations of nitrate plus nitrite, phosphate, ammonia and silicon were measured with an automatic chain (SAN ${ }^{\text {plus }}$ segmented flow analyser, Skalar, Breda, The Netherlands). From the sediment sample, median grain size was determined in the laboratory with a Coulter Counter LS particle size analyser. Light intensity was measured by means of a portable PAR radiation sensor and measuring unit (Skye Instruments, Llandrindod Wells, UK). The Coastal Waterways' Division of the Department of Environment and Infrastructure (Ministry of the Flemish Community) provided measurements of hydrodynamic variables at the moment of sampling such as wave height, and wind speed and direction.

Data treatment. The exact water height at the moment of sampling was derived from the tide curve from the nearest harbour (Nieuwpoort), obtained from the Coastal Waterways' Division of the Department of Environment and Infrastructure (Ministry of the Flemish Community). Catch densities are expressed as number of individuals per $100 \mathrm{~m}^{2}$. 'Epibenthos' and 'hyperbenthos' are used here as working definitions, indicating all animals caught with the beam trawl and sledge, respectively. Exceptions are small crustaceans (e.g. isopods, mysids), early postlarval fish (e.g. clupeids) and sedentary animals (e.g. the starfish Asterias rubens), which were excluded from further analyses of the epibenthos, and large fish, Scyphozoa, adult shrimps and crabs, and molluscs, which were excluded from the hyperbenthos analysis.

Multivariate statistical techniques were used to detect distribution patterns within the epibenthic data: correspondence analysis (Ter Braak 1986, 1988) and 2-way indicator species analysis (TWINSPAN, Hill 1979). A 4th root transformation (Field et al. 1982) was performed on the abundance data before the analyses. To assess the importance of the measured variables in structuring the community, the forward selection option together with the Monte Carlo permutation test in the Canoco package were used before canonical correspondence analyses. If variables were significantly correlated (Spearman rank correlations, p < 0.05), only 1 of them was retained for further analysis. Since wind direction is a circular variable, it was transformed to a linear variable by using the cosine of the angle that the wind made on a set of axes aligned perpendicularly 
onshore at each site (Clark et al. 1996, Zar 1996). Offshore winds at each site were allocated the greatest values $(+1)$ and onshore winds the lowest $(-1)$, while winds with a cross-shore component from either direction received scores between +0.9 and -0.9 . Wave height was expressed as the height that was reached by $33 \%$ of the waves. The state of tide at the moment of sampling was represented by the time relative to the closest high water, from low water $6 \mathrm{~h}$ before high water to $6 \mathrm{~h}$ after high water. Cosines and sines of the angular equivalent of the state of the cycle $(2 \pi \times$ [time relative to time of high water]/12.5 h) were included in the analyses (Zar 1996). The cosines reflect changes from low water to high water while sines reflect differences between incoming (flood) and outgoing (ebb) water. To evaluate the effects of the selected variables and the effects of their mutual interaction on the epibenthos, ANOVAs were performed on $\log (x+1)$ transformed density data and number of species. As the sampling scheme is inherently unbalanced (unequal number of combinations) the complete multiple regression was computed. To test the hypothesis that the effects are zero, Type III of the sum of squares was used, appropriate for any unbalanced ANOVA design with no missing cells (Milliken \& Johnson 1984). If the assumptions for ANOVA were not met, non-parametric statistics were used (Kruskal-Wallis and Mann-Whitney $U$-tests).

\section{RESULTS}

\section{Hydrodynamic conditions}

Around the moment of sampling (from 23 April 1996 until the end of 1 May 1996), 33\% of the waves measured on average ( \pm SE) $45 \pm 1 \mathrm{~cm}$ and wind speed was on average $5 \pm 0.01 \mathrm{kn}$. At least 1 period of heavy wave action was detected (Fig. 2a,b): it reached its peak at the end of the intermediate $24 \mathrm{~h}$ cycle with $33 \%$ of the waves $>150 \mathrm{~cm}$ and with a wind speed of $>15$ knots. Although a 2nd peak was distinguished at the begin-

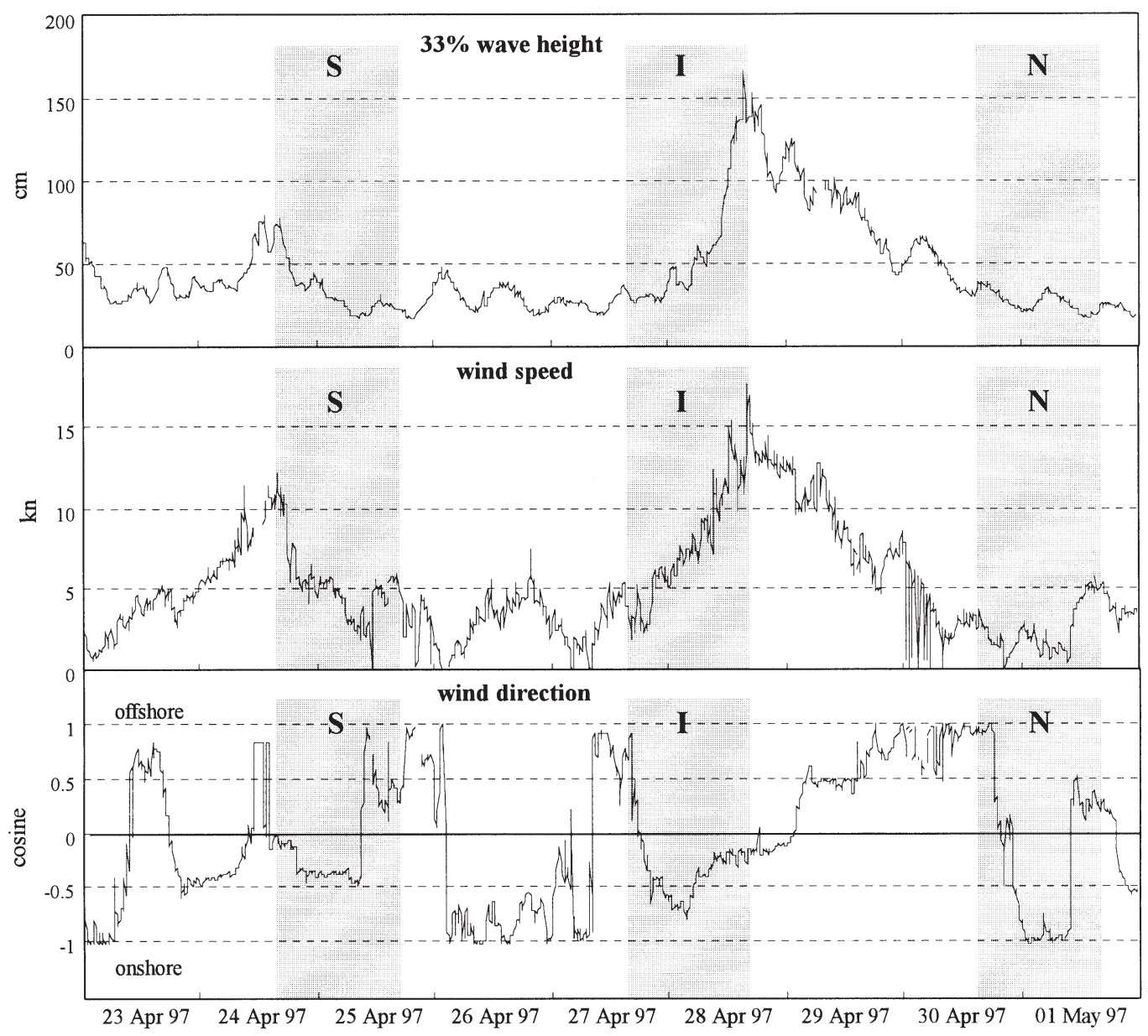

Fig. 2. Daily variation (Central European Time) of hydrodynamic variables around the period of sampling; $24 \mathrm{~h}$ sampling campaigns are indicated as the shaded areas S (spring tide), I (intermediate tide) and N (neap tide) 
ning of the first $24 \mathrm{~h}$ cycle, $33 \%$ of the waves did not exceed $100 \mathrm{~cm}$. The prevailing winds were offshore or longshore during the sampling campaign (Fig. 2c), except during the last $24 \mathrm{~h}$ cycle, when onshore winds prevailed. During the last $24 \mathrm{~h}$ cycle, a dense mist depressed the light intensity until $7.30 \mathrm{~h}$.

\section{Rhythmic changes in catch of dominant epibenthic species and hyperbenthos}

A total of 24 epibenthic species were caught: 16 fish, 2 caridean shrimp, 2 brachyuran crabs, 2 molluscs and 2 scyphozoans (Table 1). On average $20 \pm 1$ species were recorded per $24 \mathrm{~h}$ cycle. The brown shrimp Crangon crangon accounted on average for $>90 \%$ of the total epibenthic community during all 3 cycles. Without this species, juvenile plaice Pleuronectes platessa accounted for more than $20 \%$ during all cycles. Other important species are given in Table 2. Maximum total catch density was found around ebb tide (Fig. 3) and reached over 250 ind. per $100 \mathrm{~m}^{2}$.

After exclusion of 3 outliers, both TWINSPAN and correspondence analysis (eigenvalues of the first 3 axes: $0.258,0.213$ and 0.191 , respectively) resulted in the same pattern: 2 groups of samples were distinguished (TWINSPAN groups are indicated in Fig. 4). After forward selection and Monte Carlo permutation tests, only water temperature and cosine (tide) were retained. These 2 variables accounted for $15 \%$ of the variance within the dataset in a subsequent canonical
Table 1. Species list and summary of significant differences of Mann-Whitney $U$ and Kruskal-Wallis tests: ${ }^{*} 0.01<\mathrm{p}<0.05{ }^{*}{ }^{* *} 0.001<\mathrm{p}<0.01 ;{ }^{* * *} \mathrm{p}<0.001$. ns: not significant, - : see Table 3

\begin{tabular}{|lccc|}
\hline & $\begin{array}{c}\text { Tide } \\
\text { Mann-Whitney } \\
\text { U-test }\end{array}$ & $\begin{array}{c}\text { Day/night } \\
\text { Mann-Whitney } \\
\text { U-test }\end{array}$ & $\begin{array}{c}\text { Cycle } \\
\text { Kruskal-Wallis } \\
\text { test }\end{array}$ \\
\hline Total density & $* * *$ & $*$ & $\mathrm{~ns}$ \\
Scyphozoa species & $\mathrm{ns}$ & $\mathrm{ns}$ & $*$ \\
Cyanea lamarckii & $\mathrm{ns}$ & $\mathrm{ns}$ & $* *$ \\
Aurelia aurita & $\mathrm{ns}$ & $\mathrm{ns}$ & $\mathrm{ns}$ \\
Palaemon serratus & $\mathrm{ns}$ & $\mathrm{ns}$ & $\mathrm{ns}$ \\
Crangon crangon & $* * *$ & $*$ & $\mathrm{~ns}$ \\
Liocarcinus holsatus & $\mathrm{ns}$ & $\mathrm{ns}$ & $\mathrm{ns}$ \\
Carcinus maenas & $* * *$ & $\mathrm{~ns}$ & $\mathrm{~ns}$ \\
Opistobranchia spp. & $\mathrm{ns}$ & $\mathrm{ns}$ & $\mathrm{ns}$ \\
Sepiola atlantica & $*$ & $\mathrm{~ns}$ & $\mathrm{~ns}$ \\
Clupea harengus & $\mathrm{ns}$ & $\mathrm{ns}$ & $* *$ \\
Sprattus sprattus & $\mathrm{ns}$ & $\mathrm{ns}$ & $\mathrm{ns}$ \\
Ciliata mustela & $\mathrm{ns}$ & $\mathrm{ns}$ & $\mathrm{ns}$ \\
Atherina presbyter & $\mathrm{ns}$ & $\mathrm{ns}$ & $\mathrm{ns}$ \\
Syngnathus rostellatus & $*$ & $\mathrm{~ns}$ & $\mathrm{~ns}$ \\
Zoarces viviparus & $\mathrm{ns}$ & $\mathrm{ns}$ & $\mathrm{ns}$ \\
Echiichthys vipera & $\mathrm{ns}$ & $\mathrm{ns}$ & $\mathrm{ns}$ \\
Ammodytes tobianus & $\mathrm{ns}$ & $\mathrm{ns}$ & $\mathrm{ns}$ \\
Pomatoschistus lozanoi & $\mathrm{ns}$ & $\mathrm{ns}$ & $\mathrm{ns}$ \\
Pomatoschistus microps & $\mathrm{ns}$ & $\mathrm{ns}$ & $\mathrm{ns}$ \\
Pomatoschistus minutus & $\mathrm{ns}$ & $\mathrm{ns}$ & $\mathrm{ns}$ \\
Pomatoschistus spp. & $\mathrm{ns}$ & $\mathrm{ns}$ & $\mathrm{ns}$ \\
Scophthalmus maximus & $\mathrm{ns}$ & $\mathrm{ns}$ & $\mathrm{ns}$ \\
Pleuronectes flesus & $* *$ & $\mathrm{~ns}$ \\
Pleuronectes platessa & - & - & \\
Solea solea & $*$ & & \\
& & & \\
\hline
\end{tabular}

Table 2. Relative species composition of the epibenthos (\%) and total density \pm SE (ind. $100 \mathrm{~m}^{-2}$ ) per 24 h cycle (averages of all samples per cycle)

\begin{tabular}{|lclccc|}
\hline \multicolumn{3}{l}{ Spring tide } & \multicolumn{2}{l}{ Intermediate tide } & \multicolumn{2}{l}{ Neap tide } \\
\hline Crangon crangon & 96.3 & Crangon crangon & 91.7 & Crangon crangon \\
Without C. crangon & & & & \\
Pleuronectes platessa & 34.2 & Clupea harengus & 52.4 & Cyanea lamarckii & 49.1 \\
Sprattus sprattus & 26.5 & Pleuronectes platessa & 29.0 & Pleuronectes platessa & 22.1 \\
Carcinus maenas & 15.8 & Pomatoschistus lozanoi & 6.0 & Carcinus maenas & 11.1 \\
Pomatoschistus minutus & 5.9 & Carcinus maenas & 3.8 & Clupea harengus & 5.9 \\
Pomatoschistus lozanoi & 3.5 & Solea solea & 1.7 & Solea solea & 3.8 \\
Others & 14.2 & Others & 7.1 & Others & 8.1 \\
Total density \pm SE & $94 \pm 28$ & & $85 \pm 24$ & & $53 \pm 20$ \\
\hline
\end{tabular}




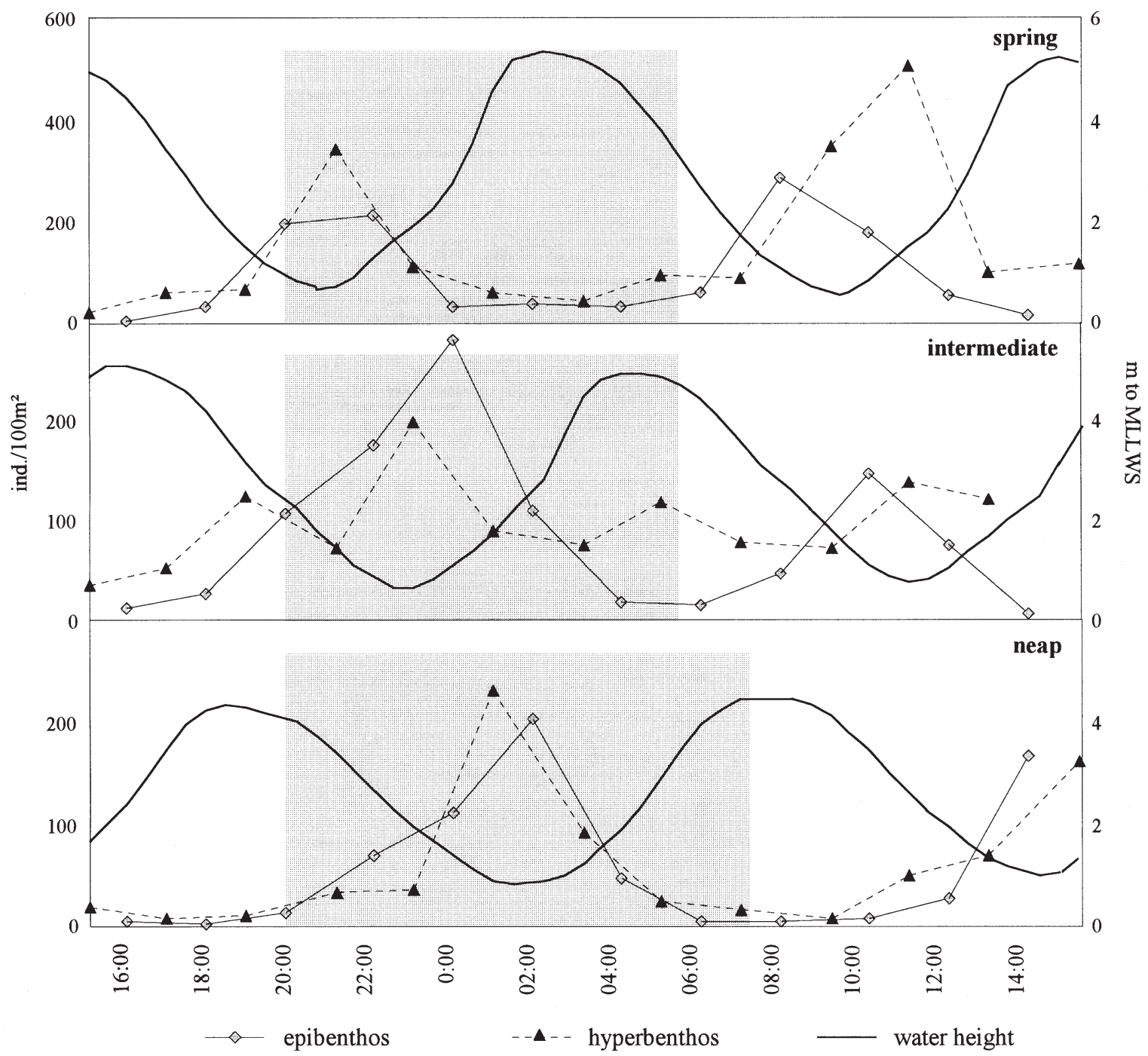

Fig. 3. Hourly variation (Central European Time) in total density of the epi- and hyperbenthos (ind. $100 \mathrm{~m}^{-2}$ ) and water height ( $\mathrm{m}$ to mean low low water spring [MLLWS]) during the three $24 \mathrm{~h}$ cycles at spring and neap tide and during the intermediate tide. The darker area indicates the dark hours

maximum of $11.6^{\circ} \mathrm{C}$ at spring tide to $13.3^{\circ} \mathrm{C}$ and $14.4^{\circ} \mathrm{C}$ during the subsequent $24 \mathrm{~h}$ cycles), the effect of time (reflected in the $3 \times 24 \mathrm{~h}$ cycles) could not be neglected. The single and combined effects of tide, day/night and $24 \mathrm{~h}$ cycle on total and individual species catch density and number of species were tested using 3-way ANOVA. However, only the number of species and the catch density of juvenile plaice met the assumptions of ANOVA (Table 3). The number of species was significantly $(p<0.05)$ higher around low water $(7 \pm 1)$ and during the day $(7 \pm 1)$ than at high water $(4 \pm 0.3)$ and during the night $(5 \pm 0.4)$. Also the combined effect tide by day/night on the number of species was significant. The effect of time represented by the three $24 \mathrm{~h}$ cycles was, however, not significant. Tide, day/night and $24 \mathrm{~h}$ cycle all had significant effects on the distribution pat- terns of juvenile plaice: the highest catch densities were found at low water $\left(1.8 \pm 0.3\right.$ ind. $\left.100 \mathrm{~m}^{-1}\right)$, during the day $\left(1.9 \pm 0.3\right.$ ind. $\left.100 \mathrm{~m}^{-1}\right)$ and during the intermediate $24 \mathrm{~h}$ cycle $\left(2.5 \pm 0.5\right.$ ind. $\left.100 \mathrm{~m}^{-1}\right)$, compared with high water $\left(0.9 \pm 0.2\right.$ ind. $\left.100 \mathrm{~m}^{-1}\right)$, night $(1.1 \pm 0.3$ ind $\left.100 \mathrm{~m}^{-1}\right)$ and the other two $24 \mathrm{~h}$ cycles $(<1.5$ ind. $\left.100 \mathrm{~m}^{-1}\right)$. Combined effects were not significant.

The assumptions for ANOVA for the total catch density and the individual catch density of the other species were not met; therefore, only the single effect of the 3 variables could be evaluated by means of Mann-Whitney $U$ (tide, day/night) or Kruskal-Wallis (cycle) tests (Table 1). Total catch density was also found to be significantly ( $\mathrm{p}<0.05)$ higher around low water $\left(130 \pm 20\right.$ ind. $\left.100 \mathrm{~m}^{-2}\right)$ than high water $(30 \pm$ 7 ind. $100 \mathrm{~m}^{-2}$ ), but catch densities were lower during 


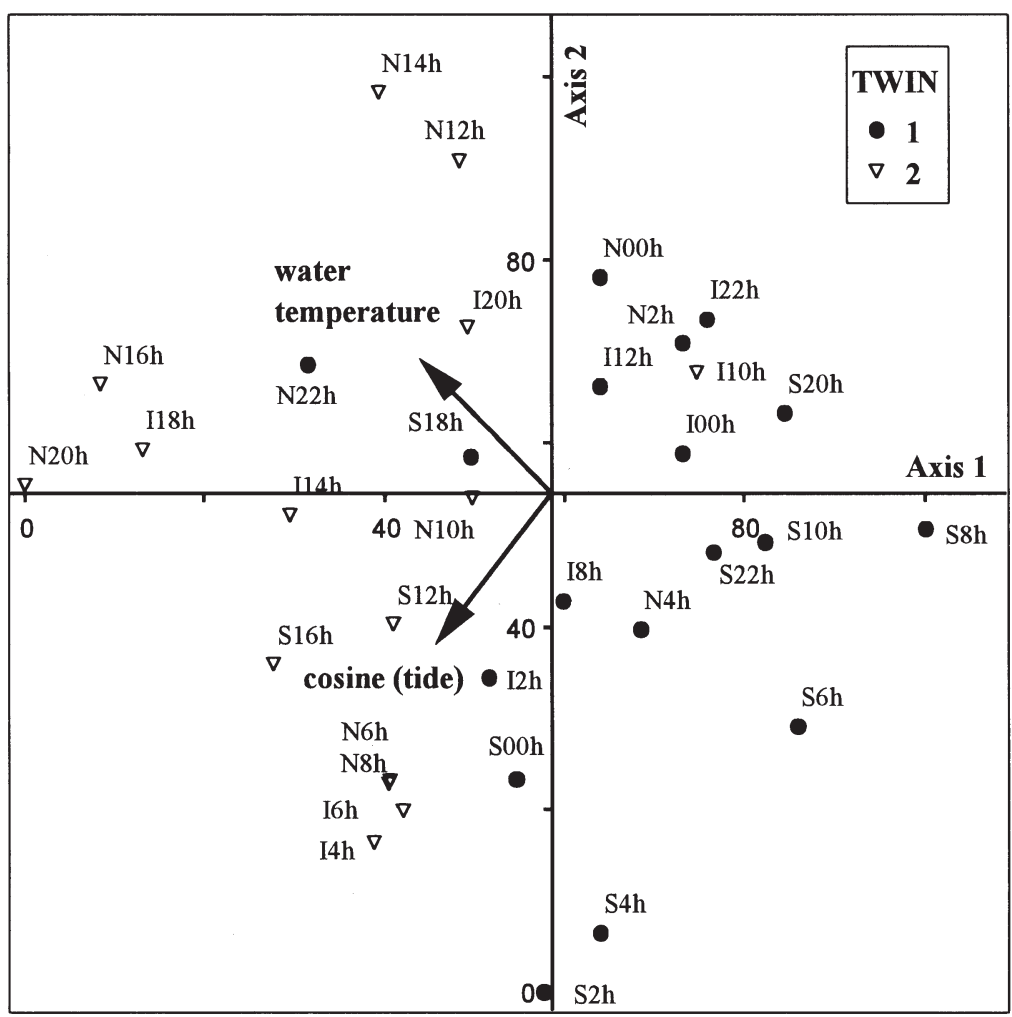

Fig. 4. Sample plots of the final canonical correspondence analysis with indication of groups (codes of samples consist of the $24 \mathrm{~h}$ cycle $[\mathrm{S}, \mathrm{I}, \mathrm{N}$ ] together with the hour of sampling). Each axis is scaled in proportion to the longest axes

the night $\left(60 \pm 20\right.$ ind. $100 \mathrm{~m}^{-2}$ and $100 \pm 20$ ind. $100 \mathrm{~m}^{-2}$, respectively). These latter results mainly reflected the distribution patterns found for the brown shrimp as this species strongly dominated the samples. The only other species for which significant differences were found between tide and time of day was juvenile sole Solea solea. This species was also more abundant at low water and during the night $\left(0.18 \pm 0.07\right.$ ind. $100 \mathrm{~m}^{-2}$ and $0.22 \pm 0.07$ ind. $100 \mathrm{~m}^{-2}$, respectively). At high water and during the day it was virtually absent $\left(<0.05\right.$ ind. $\left.100 \mathrm{~m}^{-2}\right)$. For the remaining species, only 1 of the 3 possible effects was significant (e.g. tide was important for the shore crab Carcinus maenas) and the catch densities of juvenile herring Clupea harengus and sand goby Pomatoschistus minutus differed among the three $24 \mathrm{~h}$ cycles.

The hyperbenthos consisted mainly of mysids $(80 \%$ during spring tide and $>25 \%$ during the other two $24 \mathrm{~h}$ cycles) and fish in early life stages $(14 \%$ during spring tide and $>30 \%$ during the other 2 cycles). During the intermediate and neap tide cycles, larval polychaetes $( \pm 18 \%)$ and cnidarians were also important $(5 \%$ and $14 \%$, respectively). Maximum total density and biomass of the hyperbenthos were also found around ebb tide (Fig. 3). Densities generally ranged from 200 ind. $100 \mathrm{~m}^{-2}$ to peaks of more than 4000 ind. $100 \mathrm{~m}^{-2}$, while biomass reached up to $8000 \mathrm{mg}$ ADW $100 \mathrm{~m}^{-2}$.

\section{Abundance and length distribution of the brown shrimp and juvenile plaice}

For both of the most important species, the brown shrimp and juvenile plaice, 2 cohorts were distinguished at the moment of sampling. For the brown shrimp, median standard length was 22 and $32 \mathrm{~mm}$, respectively; for plaice it was 30 and $70 \mathrm{~mm}$ (probably 0-group and I-group plaice). Both cohorts of the brown shrimp showed the same distribution pattern during the three $24 \mathrm{~h}$ cycles (data not shown). For juvenile plaice, however, 2 different patterns were observed (Fig. 5): the 0-group showed no clear abundance pattern, whereas the I-group plaice clearly performed a tidal migration pattern with highest catch densities during ebb tide.
Table 3. Three-way ANOVA: summary of significant differences. ${ }^{*} 0.01<\mathrm{p}<0.05$; ${ }^{* *} 0.001<\mathrm{p}<0.01 ;{ }^{* * *} \mathrm{p}<0.001$. ns: not significant

\begin{tabular}{|lccccc|}
\hline \multirow{2}{*}{ Effect } & df & \multicolumn{3}{c}{ No. species } & \multicolumn{3}{c|}{ Pleuronectes platessa } \\
& & $F$ & $\mathrm{p}$ & $F$ & $\mathrm{p}$ \\
\hline Tide & 1 & 16.99 & ${ }^{* * *}$ & 5.36 & ${ }^{*}$ \\
Day/night & 1 & 4.59 & ${ }^{*}$ & 4.92 & ${ }^{*}$ \\
Cycle & 2 & 0.38 & $\mathrm{~ns}$ & 4.94 & ${ }^{*}$ \\
Tide $\times$ day/night & 1 & 7.76 & ${ }^{*}$ & 1.03 & $\mathrm{~ns}$ \\
Tide $\times$ cycle & 2 & 0.11 & $\mathrm{~ns}$ & 0.59 & $\mathrm{~ns}$ \\
Day/night $\times$ cycle & 2 & 2.09 & $\mathrm{~ns}$ & 0.20 & $\mathrm{~ns}$ \\
Tide $\times$ day/night $\times$ cycle & 2 & 1.19 & $\mathrm{~ns}$ & 0.76 & $\mathrm{~ns}$ \\
\hline
\end{tabular}

\section{Stomach content and feeding rhythm of juvenile plaice}

The stomach contents of 122 plaice were analysed: 29 (13 empty) of the 0-group and 93 (18 empty) of the I-group. The diet of the 0 - and I-group plaice differed substantially (Table 4): a clear shift in diet was observed. For the 0 -group the most abundant prey items were palps of the polychaete Magelona papillicornis $(30 \%)$, fol- 


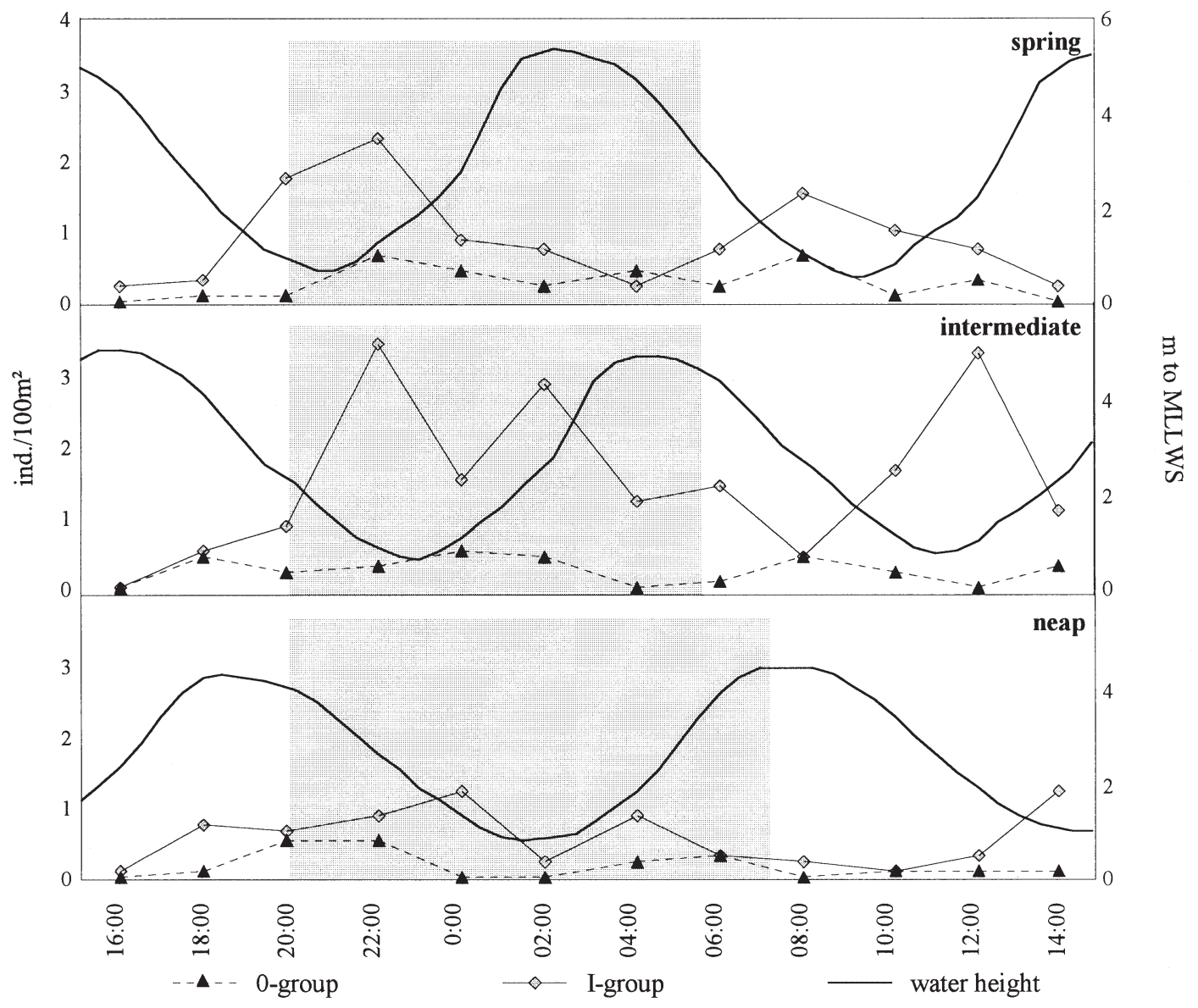

Fig. 5. Hourly variation (Central European Time) in catch density of the 0- and I-group plaice (ind. $100 \mathrm{~m}^{-1}$ ) and water height (m to MLLWS) during the three $24 \mathrm{~h}$ cycles during $\mathrm{S}$, I and $\mathrm{N}$. The darker area indicates the dark hours

Table 4. Numerical $(\% \mathrm{~N})$ and gravimetrical (\%G) diet composition of the 0 and I-group plaice, with indication of the number of fish analysed. p: palps, cl: cyprid larvae, s: siphons

\begin{tabular}{|lcccc|}
\hline & \multicolumn{2}{c}{ \% N } & \multicolumn{2}{c|}{$\% \mathrm{G}$} \\
& 0-group & I-group & 0-group & I-group \\
\hline No. fish analysed & 29 & 93 & 29 & 93 \\
No. stomachs empty & 13 & 18 & 13 & 18 \\
Pygospio elegans & 11.7 & 10.4 & 5.7 & 0.9 \\
Scolelepis squamata & 0.7 & 9.1 & 6.7 & 70.0 \\
Polydora spp. & 2.1 & 0.9 & & \\
Spio spp. & 11.7 & 4.9 & 6.8 & 0.5 \\
Polychaeta spp. & 1.4 & 3.4 & & \\
Magelona papillicornis p & 30.3 & 14.1 & 6.9 & 0.5 \\
Arenicola spp. end & & & 0.0 & 15.5 \\
Polychaeta spp. p & 6.9 & 4.6 & & \\
Nematoda spp. & & 18.1 & & \\
Harpacticoida spp. & 2.1 & 0.1 & & \\
Centropages hamatus & 5.5 & 0.1 & 15.8 & 0.0 \\
Temora longicornis & 3.4 & 0.1 & 9.9 & 0.0 \\
Cirripedia spp. cl & 14.5 & 8.6 & 6.5 & 0.6 \\
Bathyporeia spp. & 3.4 & 6.0 & 37.0 & 6.5 \\
Bivalvia spp. spat & & 3.5 & & \\
Bivalvia spp. s & 1.4 & 3.5 & & \\
Others & 8.3 & 13.8 & 4.7 & 7.9 \\
\hline
\end{tabular}

lowed by cirripedes (cyprid larvae, 14\%), and the polychaetes Pygospio elegans and Spio species (each $12 \%$ ). Gravimetrically, the amphipod Bathyporeia species was most important $(37 \%)$, followed by the hyperbenthic calanoid copepods Centropages hamatus $(16 \%)$ and Temora longicornis $(10 \%)$. The diet of I-group plaice also included other prey items (endobenthic): freeliving nematodes $(18 \%$, e.g. Pseudonchus deconincki, Mesacanthion species and Daptonema tenuispiculum) and the polychaete Scolelepis squamata (9\%) were numerically abundant. Gravimetrically only S. squamata $(70 \%)$ and the hind parts of Arenicola species (16\%) were important.

Maximal average FIs of the I-group were recorded a few hours after high water, with highest values during the first period of the $24 \mathrm{~h}$ cycle (Fig. 6). FIs of the 0-group were very erratic but they are not shown since only 16 individuals were taken into account. 


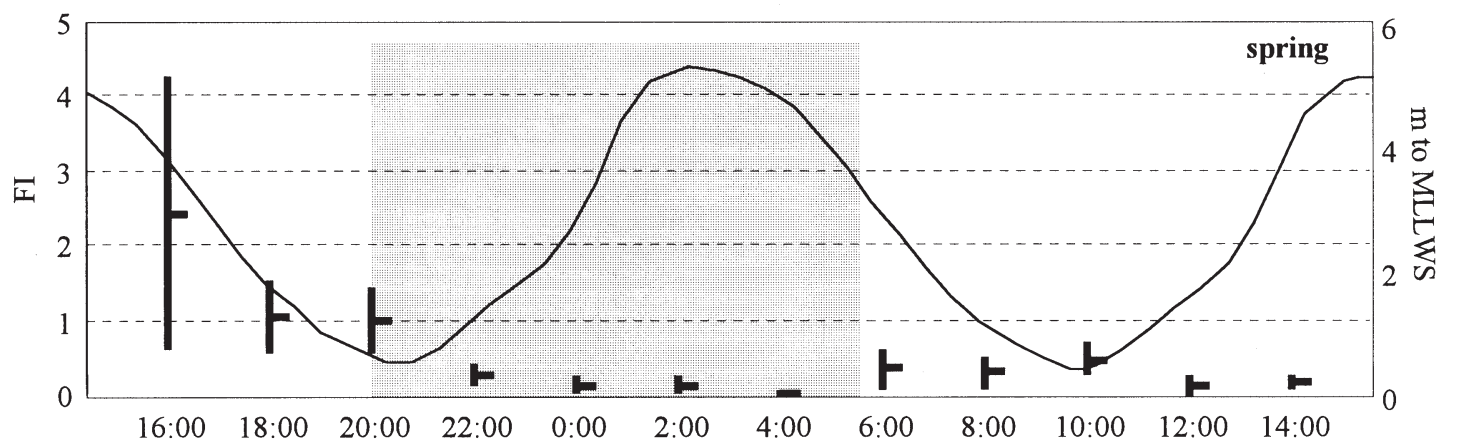

Fig. 6. Hourly variation (Central European Time) of the fullness index (FI) (mean \pm SE) calculated for the I-group plaice during the $24 \mathrm{~h}$ cycle at spring tide. The darker area indicates the dark hours

Table 4. Relative species composition of the hyperbenthos (\%) and total density $\pm \mathrm{SE}$ (ind. $100 \mathrm{~m}^{-2}$ ) per $24 \mathrm{~h}$ cycle (averages of all samples per cycle) ${ }^{*}<0.05 \%$. u.i.: unidentified

\begin{tabular}{|c|c|c|c|}
\hline & Spring tide & $\begin{array}{l}\text { Intermediate } \\
\text { tide }\end{array}$ & Neap tide \\
\hline Cnidaria & $*$ & 5.0 & 14.0 \\
\hline Ctenophora & 5.1 & 6.6 & 0.1 \\
\hline Polychaeta & 0.1 & 17.9 & 18.4 \\
\hline Copepoda & $*$ & 0.9 & 0.3 \\
\hline Caridea & 7.5 & 14.1 & 7.7 \\
\hline Anomura & - & ${ }^{*}$ & $*$ \\
\hline Brachyura & $*$ & 0.7 & 0.1 \\
\hline Cumacea & 0.1 & 0.2 & 0.4 \\
\hline Mysidacea & 79.5 & 26.4 & 31.1 \\
\hline Isopoda & 0.7 & 1.0 & 0.7 \\
\hline Amphipoda & 0.9 & 1.4 & 1.7 \\
\hline Euphausiacea & $*$ & * & $*$ \\
\hline Mollusca & - & * & * \\
\hline Echinodermata & - & - & * \\
\hline Chaetognatha & ${ }^{*}$ & $*$ & $*$ \\
\hline Pisces & 4.9 & 8.7 & 12.6 \\
\hline Pisces eggs & 1.2 & 15.1 & 12.7 \\
\hline u.i. & - & - & 0.2 \\
\hline \multicolumn{2}{|c|}{ Total density \pm SE $1500 \pm 420$} & $970 \pm 130$ & $580 \pm 190$ \\
\hline
\end{tabular}

\section{DISCUSSION}

\section{Rhythmic changes}

The dominant epibenthic species found during this study are numerically dominant in most studies of epibenthic macrocrustaceans and demersal fish in shallow waters in the Northeast Atlantic region (Macer 1967, Pihl \& Rosenberg 1982, Evans 1983, Gibson et al. 1993). Catch densities reported probably do not represent true abundances because the efficiency of the $2 \mathrm{~m}$ beam trawl is unknown for most species. The catch density of the species recorded and the species richness are a function of their distribution with depth and substratum type, their ability to avoid the gear, the size selectivity of the meshes, and many other local condi- tions such as water temperature and turbidity (Kuipers et al. 1992). Highest catch densities of most species were found around ebb tide. In areas with large tidal ranges, the sandy beach fauna often follows the tide, thereby using the upshore areas for feeding and as a refuge from predation during high tide (Gibson 1973, Van der Veer \& Bergman 1986, Ansell \& Gibson 1990). Burying behaviour by shrimp (especially juvenile individuals) in the intertidal area as the water retreats has been described by many authors (e.g. Beukema 1976, Janssen \& Kuipers 1980). Since both cohorts of the brown shrimp showed the same distribution pattern during the three $24 \mathrm{~h}$ cycles, it seems unlikely that they bury themselves as the water retreats. The former studies deal with more sheltered areas such as the Wadden Sea. The surf zone of the Belgian sandy beaches is probably too dynamic to allow this kind of behaviour.

Some species were found to be more abundant at night (e.g. Lozano's goby and juvenile sole), suggesting an onshore migration at dusk and a subsequent offshore migration by dawn or reflecting nocturnal behaviour (e.g. sole; Kruuk 1963). This diurnal movement pattern has already been described by several authors (e.g. for gadoid species: Pihl 1982, Keats \& Steele 1992, Gibson et al. 1998) although the patterns of movement and the possible explanations differ among areas. Net avoidance might also have been greater during the day as reported by Gibson et al. (1996) for gadoids. However, in contrast to the findings of Gibson et al. (1996), the total number of species caught in the present study was highest during the day. The circadian pattern as described for clupeids (e.g. Stickney 1972), is also suggested during our study as they were caught exclusively by daylight independently of the tidal cycle. Finally, differences among the three $24 \mathrm{~h}$ cycles might be explained by several factors: the increase over time of the water temperature (appearance of new recruits), the existence of semilunar distribution patterns for some species or the pre- 
vailing hydrodynamic conditions. The last can be responsible for wind induced transport of organisms towards the shore in case of prevailing offshore winds (possibly, for example, for the cnidarian Cyanea lamarckii, which was most abundant during the neap tide 24 h cycle).

Water temperature and tide (and correlated variables) were indeed indicated by the multivariate analyses as the most important structuring variables; water temperature reflected both the effect of day and night, and differences between $24 \mathrm{~h}$ cycles. Univariate statistical techniques confirmed that in general, tide, but also the diurnal cycle and the differences between the $24 \mathrm{~h}$ cycles, most likely influenced species richness, and total and individual catch densities of several species. The first hypothesis can be rejected since clear tidal and diurnal distribution patterns were found despite the turbulence characteristic for the surf zone. However, integration of the results of similar situations in future research (i.e. in such a way that more than 1 spring intermediate and neap tide cycle are sampled), should improve the reliability of these results. Overall it is likely that the behaviour patterns are a mixture of responses to the physical environment modified by direct interactions with other organisms such as predators, competitors or prey (Burrows 1994, Gibson et al. 1998). Data on predators are not available from the studied area, but they are probably largely negligible. The interaction with hyper- and macrobenthic prey will be further discussed on the basis of juvenile plaice. Other flatfish species as potential competitors of plaice in the surf zone of the Belgian coast are discussed in Beyst et al. (1999).

\section{Pleuronectes platessa}

According to Gibson (1973) the basic rhythm of juvenile plaice is circadian, but under tidal conditions it can be entrained to keep phase with the tides. The 2 cohorts of juvenile plaice present at the time of sampling clearly have different strategies. Although densities were very low, the small 0-group individuals seem to follow the water mass (actively or passively) as it enters and retreats from the beach. The larger I-group juveniles must perform tidal rhythmic behaviour as they were caught in significantly higher densities at low tide.

Young plaice feed mainly on macro- and hyperbenthic organisms (e.g. Beyst et al. 1999), both of which are more abundant near the intertidal area than in the deeper (5 to $10 \mathrm{~m}$ ) adjacent subtidal (Degraer 1999, Cattrijsse \& Dewicke in press, Beyst et al. in press). The 0-group plaice examined during this study fed more on hyperbenthic animals (e.g. calanoid copepods) than did the larger individuals. These results are in accordance with those of Kuipers (1973): 0-group plaice fed mainly on mysids and small shrimps, whereas the diet of the I-group consisted mainly of the posterior parts of Arenicola species. They are, however, in contrast to the findings of Lockwood (1984), who found that plaice of 20 to $40 \mathrm{~mm}$ basically had a grazing diet (e.g. harpacticoid copepods), whereas the I-group fed mainly on mobile prey (e.g. amphipods, polychaetes, cumaceans). He suggested that young plaice preferably consume commonly occurring species, which was also supported by Wyche \& Shackley (1986). The hyperbenthos also reached its maximum density and biomass around ebb tide. Hyperbenthic organisms either disperse actively on the beach at high water and are concentrated along the water's edge as the water retreats or are more abundant in somewhat deeper waters $(1$ to $<5 \mathrm{~m})$. Macrobenthic density and biomass on a nearby beach were found to be highest at the mean high water neap tide level (5500 ind. $\mathrm{m}^{-2}$ and $2000 \mathrm{mg} \mathrm{ADW} \mathrm{m}{ }^{-2}$, respectively) and lowest between the mean tidal and mean low water neap tide level (Degraer et al. 1999). I-group plaice fed mainly on prey typically from the intertidal (e.g. the polychaete Scolelepis squamata, Elliott et al. 1996). They clearly profit from the rich area higher on the beach when the water covers the beach and are concentrated along the water's edge at ebb tide in anticipation of high water. Berghahn (1987) also found that in the Wadden Sea, larger juvenile plaice migrate further from the channels onto the tidal flats. Next to more hyperbenthic prey, 1 of the major prey items of the smaller 0-group plaice were palps of the polychaete Magelona papillicornis. This species (and other prey items) is found mostly in somewhat deeper waters (Elliott et al. 1996, Degraer et al. 1999), suggesting that these small juveniles do not feed on the beach but at deeper sites. These results suggest an opportunistic utilisation of the available food resources by juvenile plaice. The occurrence of this phenomenon has already been described (e.g. Lasiak \& McLachlan 1987, Beyst et al. 1999). It can be an important strategy for animals frequenting physically stressed environments such as surf-exposed beaches. Young plaice generally prefer more sheltered areas (Riley et al. 1981), but still they are found in higher densities in the surf zone of the studied area than in the adjacent shallow subtidal (B.B. unpubl. data). Moreover, since 0-group plaice were found in equal catch densities during the whole tidal cycle, their presence in the intertidal area might be explained by avoidance of predators or passive transport by the surf zone currents. However, these results should be interpreted with care, as only very low densities were caught.

Finally, it is interesting to note that the FIs of the I-group were higher when wave height was greater. 
These results suggest that there may be longer term patterns in feeding success of these animals. Moreover, the second hypothesis that the strong turbulence within the surf zone inhibits the active foraging behaviour in the intertidal area is hereby rejected for the I-group plaice, at least for the conditions met during this study. The turbulence within the surf zone is generated primarily through breaking waves and to a lesser extent by shear at the bottom boundary layer. It is widely acknowledged that wave breaking at the surface provides the dominant source of water column turbulence (Holman 1995).

Acknowledgements. The intensive sampling campaign wouldn't have been successful without the help of many volunteers, and particular thanks are due to Dirk Van Gansbeke and Yves Israel. Jeroen Willekens analysed several samples and performed several stomach content analyses for his graduate thesis. Guido Dumon is thanked for the delivery of the hydrodynamic data. Ann Vanreusel provided constructive comments on earlier versions of the manuscript. Tom Gheskiere assisted with the identification of the nematodes. The first author acknowledges a grant from the Flemish Institute for the Promotion of Scientific-Technological Research (IWT). Additional financial support was obtained from Ghent University under contract BOF 98-03 12050398.

\section{LITERATURE CITED}

Ansell AD, Gibson RN (1990) Patterns of feeding and movement of juvenile flatfishes on an open sandy beach. In: Barnes M, Gibson RN (eds) Trophic relationships in the marine environment. Proc 24th Eur Mar Biol Symp. Aberdeen University Press, Aberdeen, p 191-207

Berg J (1979) Discussion of methods of investigating the food of fishes, with reference to a preliminary study of the prey of Gobiusculus flavescens (Gobiidae). Mar Biol 50:263-73

Berghahn R (1987) Effects of tidal migration on growth of 0-group plaice (Pleuronectes platessa L.) in the North Frisian Wadden Sea. Meeresforschung 31:209-226

Beukema JJ (1976) Biomass and species richness of the macrobenthic animals living on the tidal flats of the Dutch Wadden Sea. Neth J Sea Res 10:236-261

Beyst B, Cattrijsse A, Mees J (1999) Feeding ecology of juvenile flatfishes of the surf zone of a sandy beach. J Fish Biol 55:1171-1186

Beyst B, Buysse D, Dewicke A, Mees J (in press) Surf zone hyperbenthos of Belgian sandy beaches: seasonal patterns. Estuar Coast Shelf Sci

Burrows MT (1994) Foraging time strategy of small juvenile plaice: a laboratory study of diel and tidal behaviour patterns with Artemia prey and shrimp. Mar Ecol Prog Ser 115:31-39

Burrows MT, Gibson RN, Maclean A (1994) Effects of endogenous rhythms and light conditions on foraging and predator-avoidance in juvenile plaice. J Fish Biol 45(Suppl A): $171-180$

Cattrijsse A, Dewicke A (2001) Hyperbenthic biodiversity patterns of the Belgian coastal waters. In: Cattrijsse A, Vincx $M$ (eds) Biodiversity of the benthos and the avifauna of the Belgian coastal waters. Federal Office for Scientific, Technical and Cultural affairs, Brussels, p 24-26

Clark BM, Benneth BA, Lamberth SJ (1996) Temporal varia- tions in surf zone fish assemblages from False Bay, South Africa. Mar Ecol Prog Ser 131:35-47

Degraer S (1999) Macrobenthos of shallow marine habitats (Belgian coast) and its use in coastal zone management. $\mathrm{PhD}$ thesis, Ghent University

Degraer S, Mouton I, De Neve L, Vincx M (1999) Community structure and intertidal zonation of the macrobenthos on a macrotidal, ultra-dissipative sandy beach: summer-winter comparison. Estuaries 22:742-752

Edwards RL (1958) Movements of individual members in a population of the shore crab, Carcinus maenas, in the littoral zone. J Anim Ecol 27:37-46

Elliott B, Degraer S, Bursey M, Vincx M (1996) Intertidal zonation of macroinfauna on dissipative, sandy beach at De Panne (Belgium): a pilot study. Jaarboek Dodonea 64: 92-108

Evans S (1983) Production, predation and food niche segregation in a marine shallow soft-bottom community. Mar Ecol Prog Ser 10:147-157

Field JG, Clarke KR, Warwick RM (1982) A practical strategy for analysing multispecies distribution patterns. Mar Ecol Prog Ser 8:37-52

Gibson RN (1973) Tidal and circadian activity rhythms in juvenile plaice. Mar Biol 22:379-386

Gibson RN, Ansell AD, Robb L (1993) Seasonal and annual variations in abundance and species composition of fish and macrocrustacean communities on a Scottish sandy beach. Mar Ecol Prog Ser 98:89-105

Gibson RN, Robb L, Burrows MT, Ansell AD (1996) Tidal, diel and longer term changes in the distribution of fishes on a Scottish sandy beach. Mar Ecol Prog Ser 130:1-17

Gibson RN, Pihl L, Burrows MT, Modin J, Wennhage H, Nickell LA (1998) Diel movements of juvenile plaice Pleuronectes platessa in relation to predators, competitors, food availability and abiotic factors on a microtidal nursery ground. Mar Ecol Prog Ser 165:145-159

Hill MO (1979) TWINSPAN. A FORTRAN program for arranging multivariate data in an ordered two-way table by classification of the individuals and attributes. Cornell University, Ithaca

Holman R (1995) Nearshore processes. U.S. National Report to IUGG, 1991-1994 Rev Geophys 33(Suppl). Available at: http://www.agu.org/revgeophys/holman01/node10.html

Janssen GM, Kuipers BR (1980) On tidal migration in the shrimp Crangon crangon. Neth J Sea Res 14:339-348

Keats DW, Steele DH (1992) Diurnal feeding of juvenile cod (Gadus morhua) which migrate into shallow water at night in eastern Newfoundland. J Northwest Atl Fish Sci 13: 7-14

Kruuk H (1963) Diurnal periodicity in the activity of the common sole, Solea vulgaris Quensel. Neth J Sea Res 2:1-28

Kuipers B (1973) On the tidal migration of young plaice. Neth J Sea Res 6:367-388

Kuipers BR, Maccurrin B, Miller JM, van der Veer HW, Witte JIJ (1992) Small trawls in juvenile flatfish research: their development and efficiency. Neth J Sea Res 29:109-117

Lasiak TA, McLachlan A (1987) Opportunistic utilization of mysid shoals by surfzone teleosts. Mar Prog Ser 37:1-7

Lockwood SJ (1984) The daily food intake of 0-group plaice (Pleuronectes platessa L.) under natural conditions: changes with size and season. J Cons Int Explor Mer 41: 181-193

Macer CT (1967) The food web in Red Wharf Bay (North Wales) with particular reference to young plaice (Pleuronectes platessa). Helgol Wiss Meeresunters 15:560-573

Mantoura RFC, Llewellyn CA (1983) The rapid determination of algal chlorophyll and carotenoid pigments and their breakdown products in natural waters by reverse-phase 
high-performance liquid chromatography. Anal Chem Acta 151:297-314

Masselink G, Short AD (1993) The effect of tidal range on beach morphodynamics and morphology: a conceptual beach model. J Coast Res 9:785-800

Mees J (1994) The hyperbenthos of shallow coastal waters and estuaries: community structure and biology of the dominant species. $\mathrm{PhD}$ thesis, Ghent University

Milliken GA, Johnson DE (1984) Analysis of messy data, Vol I. Designed experiments. Van Nostrand Reinhold, New York

Pihl L (1982) Food intake of young cod and flounder in a shallow bay on the Swedish West coast. Neth J Sea Res 15: 419-432

Pihl L, Rosenberg R (1982) Production, abundance, and biomass of mobile epibenthic marine fauna in shallow waters, western Sweden. J Exp Mar Biol Ecol 57:273-301

Riley JD, Symonds DJ, Woolner L (1981) On the factors influencing the distribution of 0 -group demersal fish in coastal waters. Rapp P-v Reun Cons Int Explor Mer 178:223-228

Stickney AP (1972) The locomotor activity of juvenile herring

Editorial responsibility: Otto Kinne (Editor),

Oldendorf/Luhe, Germany
(Clupea harengus harengus L.) in response to changes in illumination. Ecology 53:438-455

Ter Braak CJF (1986) Canonical correspondence analysis: a new eigenvector technique for multivariate direct gradient analysis. Ecology 67:1167-1179

Ter Braak CJF (1988) CANOCO—a FORTRAN program for canonical community ordination by (partial) (detrended) (canonical) correspondance analysis (version 2.1). Report LWA-88-02, Agricultural Mathematics Group, Wageningen

Van der Veer HW, Bergman MJN (1986) Development of tidally related behaviour of a newly settled 0 -group plaice (Pleuronectes platessa) population in the western Wadden Sea. Mar Ecol Prog Ser 31:121-129

Wyche CJ, Shackley SE (1986) The feeding ecology of Pleuronectes platessa L., Limanda limanda (L.) and Scophthalmus rhombus (L.) in Carmarthen Bay, South Wales, UK J Fish Biol 29(Suppl A):303-311

Zar JH (1996) Biostatistical analysis. Prentice Hall International Editions, London

Submitted: February 19, 2001; Accepted: May 17, 2001 Proofs received from author(s): November 27, 2001 